DARIA MAZUR

Instytut Nauk o Kulturze i Religii

Uniwersytet Kazimierza Wielkiego w Bydgoszczy
Images

vol. XXVII/no. 36

Poznań 2020

ISSN 1731-450X

\title{
Między kosmopolityzmem a nazizmem - konteksty przestrzeni symbolicznych czterech filmów nakręconych przez niemieckiego operatora Franza Weihmayra
}

\begin{abstract}
Aвstract. Mazur Daria, Między kosmopolityzmem a nazizmem - konteksty przestrzeni symbolicznych czterech filmów nakręconych przez niemieckiego operatora Franza Weihmayra [Between cosmopolitanism and Nazism: the contexts of the symbolic space in four movies by the German cinematographer Franz Weihmayr]. "Images” vol. XXVII, no. 36. Poznań 2020. Adam Mickiewicz University Press. Pp. 21-40. ISSN 1731-450X. DOI 10.14746/i.2020.36.02.

The paper is a comparative analysis of the circumstances influencing symbolic spaces in four movies by Franz Weihmayr in the years 1931-1942: Dzikie Pola [Wild Fields], Halutzim, La Habanera and The Great Love. The analysis allows for delineating the development of the German cinematographer Franz Weihmayr's career, which, in the context of historical-political and ideological-artistic circumstances, can serve as an example of a broader phenomenon: a particular fluctuation of choices made by German cinematographers over the Weimar, Nazi, and post-war periods. This analysis is of pioneering importance because of the paucity of publication heretofore dedicated to Weihmayr's works, who at the time worked together with, among others, Leni Riefenstahl, Frank Wysbar, and Hans Detlef Sierck, as well as Polish directors, such as Józef Lejtes and Aleksander Ford. The framework for semiotic analyses of the symbolic spaces of the movies mentioned above are two groups of contexts connected with ideas stemming from contradictory bases: the idea of cosmopolitism and the idea of Nazism.
\end{abstract}

KEYWORDS: symbolic space, cosmopolitism, nazizm, cinema of nazi Germany, German cinematographers, Polish cinema of 1930s.

Twórczość Franza Weihmayra, operatora urodzonego w Monachium w 1903 roku, jest bardzo bogata; rozpoczyna się w okresie filmu niemego w pierwszej połowie lat dwudziestych, kończy zaś po II wojnie światowej, w drugiej połowie lat sześćdziesiątych [1]. Pracował on w ciągu półwiecza, bez dłuższych przerw, przy produkcji ponad dziewięćdziesięciu filmów[2]. Dorobek ten, rozpatrywany w kontekście uwarunkowań historyczno-politycznych i ideowo-artystycznych, stanowić może przykład szerszego zjawiska - swoistej meandryczności

[1] Franz Weihmayr zmarł 26 maja 1969 roku w Monachium. W Polsce występował jako Franz Weihmayer lub Franciszek Weimeier, a także Wajmajer. Zob. Wspomnienia Józefa Lejtesa (cz. I), „Tygiel Kultury" 1997, nr 5, s. 61.
[2] Zob. <https://www.imdb.com/name/ nmoo05925/>, dostęp: 12.03.2020. 
wyborów, których dokonywali przedstawiciele niemieckiego środowiska filmowego na przestrzeni kilku epok - weimarskiej, nazistowskiej oraz powojennej. Nie został on jednak dotąd całościowo szerzej scharakteryzowany, a sam Franz Weihmayr jako operator był jedynie wspominany przez historyków kina niemieckiego w dość lapidarny, wyrywkowy sposób, w nawiązaniu do ekranowych kreacji Zarah Leander oraz twórczości kilku reżyserów, z którymi współpracował[3]. Należy zaznaczyć, że wśród realizatorów tych byli, obok Leni Riefenstahl, Franka Wysbara, Hansa Detlefa Siercka, także dwaj reżyserzy żydowscy pochodzący z Polski - Józef Lejtes i Aleksander Ford.

Próba porównawczej analizy uwarunkowań, które wpłynęły na specyfikę przestrzeni symbolicznych w czterech filmach nakręconych przez Franza Weihmayra w latach 1931-1942 - Dzikie pola, Chalutzim (polski tytuł Sabra), La Habanera, Die große Liebe (Wielka miłość)[4], pozwala przede wszystkim na wysnucie wniosków odnoszących się do ogólnej linii rozwoju kariery tego operatora. Ma to znaczenie ze względu na wspomnianą już znikomą ilość poświęconych mu prac, jak i szczególne okoliczności jego współpracy z reżyserami z Polski, która dotąd nie stanowiła również przedmiotu szerszych studiów ani analiz. Zarazem też, pomimo iż prezentowane w tym szkicu tezy nie mają na celu zasadniczej rewizji dotychczasowych ustaleń badaczy dotyczących specyfiki kinematografii niemieckiej wspomnianego okresu, ze względu na uwzględnienie w prezentowanych tu dociekaniach czynników zarówno płynności przemian, jak i radykalnych procesów, które w niej wtedy zachodziły, możliwe jest wyakcentowanie zaznaczających się w niej sprzeczności. Ramą dla semiotycznych analiz przestrzeni symbolicznych wspomnianych filmów są więc dwa zespoły kontekstów, powiązanych z koncepcjami wyrosłymi z przeciwstawnych założeń z ideą kosmopolityzmu, żywą w Europie i inspirującą po I wojnie światowej aż do początku lat trzydziestych, oraz z ideologią nazizmu, która kształtowała polityczne, społeczne i gospodarcze tło kinematografii niemieckiej w wyniku wprowadzenia nazistowskiej dyktatury, po nominowaniu Adolfa Hitlera na kanclerza Niemiec w 1933 roku.

Pojęcie kosmopolityzmu, którego historia sięga czasów antycznych, w nowożytności zajęło ważne miejsce w oświeceniowej filozofii, a od schyłku XIX wieku stało się ośrodkiem myśli stanowiącej kontr-

[3] Zob. K. Kreimeier, The Ufa Story: A History of Germany's Greatest Film Company, 1918-1945, przeł. R. Kimber, R. Kimber, Berkeley 1996, s. 299, 317, 346, 354; J.F. Bruns, Nazi Cinema’s New Women. Marika Rokk, Zarah Leander, Kristina Soderbaum, Stanford 2002, s. 127, 130; H. Nicolella, FrankWisbar. The Director of Ferryman Maria, from Germany to America and Back, Jefferson 2017, s. 81; R. Rother, Leni Riefenstahl. The Seduction of Genius, London, New York 2002, s. 32, 51, 237-238, 258; A.K. Porter, E. Rentschler, The Ministry of Illusion: Nazi Cinema and its Afterlife,
Harvard 1996, s. 133; J. Holliday, Sirk on Sirk. Conversations with Jon Holliday, London 2010; <https:// books.google.pl/books? redir_esc $=y \& h l=p l \& i d=t U H$ chXsZoh8C\&q=Weihmayr\#v=onepage\&q=Weihma yr>, dostęp: 12.03.2020.

[4] Film Dzikie pola znany jest jedynie z opisów, recenzji oraz tekstu Leona Bruna, stanowiącego wstępny materiał na projekt scenariusza. Znajduje się on na liście dzieł zaginionych Filmoteki Narodowej. Zob. <http://www.fn.org.pl/page/index.php?str=521>, dostęp: 12.03.2020. 
propozycję dla koncepcji ufundowanych na narodowo-państwowych strukturach[5]. Idea, rozumiana jako łącząca „szacunek dla inności i odmienności z dążeniami do przygotowania nowych demokratycznych form panowania politycznego poza państwami narodowymi”[6], okazała się inspirująca dla ruchów politycznych, które przybierały w Europie na sile po I wojnie światowej (ruch paneuropejski - odwołujący się do idei Richarda Coudenhove-Kalergi)[7]. Wpisywała się w nie również popularna szczególnie wśród ówczesnej postępowej europejskiej inteligencji postawa pacyfistyczna, stanowiąca skutek wojennych traum. Należy jednak zwrócić uwagę, że modernistyczna wizja „jednego świata” ufundowana była na ściśle europocentrycznym fundamencie i w znaczącej mierze polegała na kulturowym eklektyzmie oraz międzykulturowej wymianie intelektualnych elit[8]. Idea kosmopolityzmu zaś, jako forma społecznego traktowania odmienności etnicznej, kulturalnej, sytuuje się na przeciwnym biegunie zarówno wobec „hierarchicznego podporządkowania, uniwersalistycznej i nacjonalistycznej jednorodności”, jak i narodowego partykularyzmu[9]. Warto podkreślić, że odróżnia go od tendencji uniwersalistycznych i nacjonalistycznych uznanie odmienności i różnic, które nie są podporządkowane hierarchicznie czy likwidowane, lecz akceptowane (co oznacza „postrzegać Innych jako różnych oraz jako równych" [10]) w kontekście zarówno wewnętrznym, jak i zewnętrznym. Należy zauważyć też, że kosmopolityzm i uniwersalizm łączy jednak „wyobrażenie o nieograniczonym obowiązywaniu norm”[11].

Nazizm, który wyrósł jako protest przeciwko nowoczesności i wartościom oświecenia wraz z ukształtowanymi na ich bazie poglądami politycznymi, konstytuował się wokół kategorii: „antyracjonalizmu, walki, przywództwa i elitaryzmu, narodowego socjalizmu i ultra nacjonalizmu" [12]. Oparty na działaniu, a nie intelekcie, odrzucał on również uniwersalizm i odwoływał się do idei organicznej jedności: „Wspólnotę narodową [...] postrzegano jako niepodzielną całość, w której wszelka rywalizacja czy konflikt są podporządkowane wyższemu, kolektywnemu celowi"[13]. Waloryzując pozytywnie wojnę i walkę, wraz z kultem siły nazizm głosił także jako wartości nadrzędne powinność, posłuszeństwo i poświęcenie. Radykalne odrzucenie równości łączyło się z ideą wodzostwa, na której ufundowana była totalitarna dyktatura nazistowska[14]. Reżim oparty na propagandzie i agitacji politycznej, a także kontroli wszelkich sfer życia społecznego, stawiał

[5] Zob. U. Beck, E. Grande, Europa kosmopolityczna. Społeczeństwo i polityka $w$ drugiej nowoczesności, przeł. A. Ochocki, Warszawa 2009, s. 41.

[6] Ibidem.

[7] Zob. <https://encyklopedia.pwn.pl/haslo/Paneuropa;3953811.html>, dostęp: 12.03.2020.

[8] Por. T. Bergfelder, Love beyond the nation. Cosmopolitanism and transnational desire in cinema, [w:] Europe and Love in Cinema, red. L. Passerini, J. Labanyi, K. Diehl, Bristol, Chicago 2012, s. 63.
[9] U. Beck, E. Grande, op.cit., s. 41.

[10] Ibidem, s. 43.

[11] Ibidem, s. 46.

[12] A. Heywood, Ideologie polityczne wprowadzenie, przeł. M. Habura, N. Orłowska, D. Stasiak, Warszawa 2007, s. 225.

[13] Ibidem, s. 227

[14] Zob. ibidem, s. 222, 228. 
sobie za cel ukształtowanie faszystowskiego nowego człowieka w duchu ideału aryjskości, jako przejawu skrajnego rasistowskiego nacjonalizmu, odwołującego się do biologicznego antysemityzmu i darwinizmu społecznego[15]. Zakładane zaś w ramach ideologii nazizmu narodowe odrodzenie miało prowadzić przez militarną ekspansję do panowania nad innymi narodami. Powiązane z technologią wojenną czynniki, takie jak rozwój urbanistyczny i industrializacja, mimo iż sprzeczne z propagowaną w niemieckiej wersji faszyzmu ideologią ludową sławiącą proste, bliskie natury życie na wsi, stanowiły ważny element propagandowy zaznaczający się wyraźnie w kinie III Rzeszy[16].

Józef Lejtes w wywiadzie udzielonym w sierpniu 1931 roku w Berlinie, zapowiadając realizację Dzikich pól, podkreślał, iż znalazł w niemieckiej stolicy operatora, „który ma swoje wybitne uzdolnienie i specjalny sentyment do zdjęć plenerowych"[17]. Franz Weihmayr był już wtedy współautorem zdjęć do wyreżyserowanego przez Leontine Sagan, we współpracy z kierownikiem artystycznym Carlem Froelichem, filmu Dziewczęta w mundurkach, którego przesłanie odbijało kosmopolityczne, liberalne tendencje epoki[18]. Film poddano ocenie cenzury 1 października 1931 roku, co oznacza, że w środowisku filmowym Berlina informacje o jego walorach krążyły już latem, a sam Franz Weihmayr znany był ze swoich umiejętności, nim premiera (27 listopada 1931 roku) potwierdziła je, otwierając zarazem możliwości współpracy z reżyserami poszukującymi ciekawych, niesztampowych rozwiązań artystycznych[19].

Udana kooperacja podczas zdjęć do Dzikich pól na dziewiczych terenach Polesia (okres zdjęciowy w trudnych warunkach terenowych rozpoczął się w połowie sierpnia 1931 roku i trwał ponad dwa miesiące)[20]

[15] Zob. ibidem, s. 232-233.

[16] Zob. ibidem, s. 241-242.

[17] Z. Schindler, Rozmowa o „Dzikich Polach" w Berlinie (Korespondencja własna), „Kino” 1931, nr 38. W „Kurierze Nowogródzkim” określany jest on jako świetny operator bawarski i „wynalazca barwnej taśmy” (I, Nowy film polski „Dzikie pola”, „Kurier Nowogródzki" 1931, nr 4O, s. 2). Jego wykształcenie fotograficzne było gruntowne; do 1921 roku praktykował on w fotograficznej pracowni portretowej swego ojca, uczęszczał też do Państwowej Szkoły Fotografii w Monachium. Następnie został asystentem kamery w Union Film i pracował przez parę lat w Monachium, po czym związał się ze środowiskiem filmowym Berlina. Zob. H. Spielhofer, An der Kamera. Franz Weihmayr, „Der Deutsche Film” 1938, nr 4 (April), s. 278; <https://www.filmportal.de/en/ person/franz-weihmayr_f303075915672226e03053d5 ob375262>, dostęp: 12.03.2020.
[18] Obraz ten odniósł duży sukces w Niemczech i za granicą; został nagrodzony na festiwalu w Wenecji w 1932 roku i w Tokio w 1934 roku. Recenzenci doceniali jego walory wizualne. Nad Dziewczętami w mundurkach Franz Weihmayr pracował wraz z operatorem Reimarem Kuntze, który był niemal jego równolatkiem urodzonym także w Monachium i angażowanym już wcześniej do artystycznych projektów filmowych w Niemczech (np. Berlin. Die Sinfonie der Großstadt). Zob. S. Kracauer, Od Caligariego do Hitlera. Z psychologii filmu niemieckiego, przeł. E. Skrzywanowa, W. Wertenstein, Gdańsk 2009, s. 178-179.

[19] Kolejnym projektem w stylu kina weimarskiego był film Anna i Elżbieta kręcony przez Franza Weihmayra pod kierunkiem Franka Wysbara. Zob. T. Kłys, Od Mabusego do Goebbelsa. Weimarskie filmy Fritza Langa $i$ kino niemieckie do roku 1945, Łódź 2013, s. 135. [20] Zob. Alroz, Niespodziewany wywiadowca, „Kino” 1932, nr 8. 
sprawiła zaś, że reżyser określał w swoich powojennych wspomnieniach autora zdjęć do tego filmu jako najwybitniejszego spośród operatorów, z którymi miał możliwość pracować[21]. Franz Weihmayr właściwie odczytywał i transponował na obraz filmowy wyobrażenia reżysera o krajobrazie jako elemencie narracyjnym, potrafił też wydobyć w zbliżeniach typy ludzkie, twarze jako nośnik emocji i dramatyzmu. Realizatorska koncepcja Józefa Lejtesa nawiązywała do ekranowych wizji twórców radzieckiej szkoły montażu - Lwa Kuleszowa i Wsiewołoda Pudowkina. Praca niemieckiego operatora nadała jej zaś swoisty, interesujący wyraz estetyczny, poprzez sensualizm i formalny dualizm obrazów (zderzenie kategorii dziejowości i sił natury); doceniła ją też część recenzentów, między innymi Stefania Zahorska[22]. Czynnik estetyczny został świadomie wpisany w przekaz ideowy filmu, niosącego wyraźne przesłanie pacyfistyczne, $\mathrm{w}$ powiązaniu $\mathrm{z}$ motywem zrównania bohaterów wobec wojennego doświadczenia granicznego[23].

Wyobrażenia ufundowane na plastycznym zobrazowaniu terenów Polesia kształtują przestrzeń symboliczną filmu, wspomagając elementy dyskursu kosmopolitycznego, w ramach którego wojna i militaryzm występują jako siła wyniszczająca człowieczeństwo, degradująca humanitarne wartości. Osadzenie akcji, rozgrywającej się w okresie wojny domowej w porewolucyjnej Rosji, na południe od Pińska motywowane było nie tylko względami topograficzno-historycznymi, odniesieniami do literackiego pierwowzoru scenariusza, ale również symbolicznym potencjałem znaczeniowym wspomnianej przestrzeni[24]. Zachodnia część Polesia to podmokłe obszary pograniczne, oddzielające ówcześnie Rzeczpospolitą i sowiecką Rosję. Bohaterami Dzikich pól są byli żołnierze różnych armii, cudzoziemcy, którzy uciekają z obozu jenieckiego w Rosji i w poszukiwaniu schronienia trafiają na tereny położone w dorzeczu Prypeci[25]. Estetyzowane filmowe obrazy bagien i puszczy, jako dominanta przestrzenna diegezy, pozwoliły na koncepcyjne przeciwstawienie - dramatycznych, niestałych praw historii (z którymi łączyło się też wyobrażenie obozowej izolacji) i rozległej, nieokiełznanej przestrzeni przyrody, niepodległej człowiekowi, stanowiącej constans, a zarazem dającej schronienie podczas ucieczki bohaterów z obozu. Szerokie plany kontrastowane w Dzikich polach ze

[21] Zob. Wspomnienia Józefa Lejtesa (cz. I), op.cit., s. $62-63$.

[22] Zob. S. Zahorska, Kronika filmowa, „Wiadomości Literackie" 1932, nr 13, s. 10. Okoliczności niefortunnej premiery i powstania wersji uzupełnionej przemontowanego filmu, pokazanej na pokazie prasowym w kwietniu 1932 roku, szerzej omawia Artur Petz. Zob. idem, „Sto szabel blysnęło w słońcu”. Warszawska premiera filmu Dzikie pola Józefa Lejtesa, [w:] 1918 - kino polskie wobec odzyskania niepodległości, red. M. Guzek, P. Zwierzchowski, Bydgoszcz 2020, s. $55-66$.
[23] Kontekst idei pacyfistycznej w tym filmie został przeanalizowany w artykule: D. Mazur, Pacyfistyczny duch nad Dzikimi polami, [w:] Europa Środkowo-Wschodnia. Trudny dialog, red. J. Getka, R. Kramar, Warszawa 2015, s. 89-102.

[24] Zob. L. Brun, Dzikie pola (Szkic scenariusza do filmu dźwiękowego. Prawa autorskie zastrzeżone), Cz. 1, „Kino” 1930, nr 21, s. 11; idem, Dzikie pola (Szkic scenariusza do filmu dźwiękowego. Prawa autorskie zastrzeżone), cz. 2, „Kino” 1930, nr 22, s. 11.

[25] Film kręcono w okolicach miejscowości Ładoroż, leżącej nad rzeką Styr. 
zbliżeniami wycieńczonych twarzy uciekinierów, wydobywały zarazem słabość, kruchość każdej jednostkowej egzystencji wobec wzniosłego, poetycko ukazanego ogromu sił natury, jak również wagę ludzkiej zdolności do utrzymania ponadnarodowej wspólnoty, pomagającej przetrwać w bardzo trudnych warunkach.

Specyfika krajobrazów Polesia, w których dominują rzeki i płytkie jeziora, a przede wszystkim rozległe bagna, na wyższych terenach natomiast sosnowe bory, służyła zaakcentowaniu uobecniającego się w fabule wątku deprawacji, której podlega grupa uciekinierów. Symbolika bagien jako obszaru „rozkładu duchowego”[26] odsyłała do stanu zdegradowania moralnego bohaterów, zdolnych do kradzieży i gwałtu, co potwierdzały sceny związane $\mathrm{z}$ ich przybyciem w okolice ludzkich siedzib. Filmowe obrazy sosnowych borów, poprzez ich złożoną symbolikę, jako dziewiczych i budzących grozę obszarów leśnych, kryjących to, co nierozpoznane w odniesieniu do psychiki człowieka, służyły podkreśleniu psychologicznego aspektu - nieświadomości, nieracjonalności popędów oraz mechanizmu odrzucenia kulturowych norm i moralnych hamulców, któremu ulegają byli jeńcy (wątek gwałtu dokonanego na Basi)[27]. Cudzoziemcy, w których wojna wyzwoliła zdziczenie i deprawację, występują więc wobec tubylców jako obcy przybysze łamiący uniwersalne ludzkie normy[28]. Ich zbiorowa śmierć $\mathrm{w}$ finale filmowej opowieści, jak w moralitecie, zyskuje symboliczny wymiar - w obliczu praw majestatycznej przyrody i hierarchii moralnej ocaleć mogą jedynie sprawiedliwi. Paradoks filmowego zobrazowania natury i zagubionych w niej nielicznych osad tubylców (Poleszuków, którzy uchodzili w ówczesnej Rzeczpospolitej za społeczność o najwyższym poziomie analfabetyzmu, egzystującą w bardzo prymitywnych warunkach) polegał na przesłaniu, iż wśród ostępów dzikiej przyrody, oddalonych od cywilizacji, możliwe było przechowanie uniwersalnych ludzkich wartości, które narażone są na rozpad w wyniku działania wojennej machiny. Ucieleśnieniem postaw ocalających człowieczeństwo w obliczu dramatycznej postwojennej rzeczywistości, odwołujących się do międzyludzkiej wspólnoty i jej praw, jest zakochana para bohaterów - Zbig i Basia, a także opiekun dziewczyny, który ocalił jej życie - prosty wieśniak.

Należy przypomnieć, w nawiązaniu do uwarunkowań produkcji filmu Dzikie pola, popularną w latach dwudziestych kosmopolityczną z ducha koncepcję „filmowej Europy”[29]. Zakładała ona, jako przeciwwagę dla filmowej ekspansywności Hollywood, intensywną współpracę i wymianę między narodowymi kinematografiami kontynentu, opartą na filmach przemawiających do międzynarodowej widowni. Uniwersalne przesłanie Dzikich pól wpisywało się w powyższą koncep-

[26] J.E. Cirlot, Bagno, [w:] idem, Słownik symboli, przeł. I. Kania, Kraków 2001, s. 76.

[27] Zob. idem, Las, [w:] idem, op.cit., s. 222.

[28] Por. U. Beck, E. Grande, op.cit., s. 46.

[29] K. Thompson, Narodziny i schyłek „Filmowej
Europy", [w:] Kino Europy, red. P. Sitarski, Kraków 2001, s. 23-48.

[30] O filmie jako wydarzeniu artystycznym skierowanym do wielkomiejskiej inteligencji pisali: L. Armatys, W. Stradomski, A. Petz. Zob. A. Petz, op.cit., 
cję[30]. Należy dodać, że kinematografia niemiecka miała ówcześnie dominującą pozycję wśród innych krajów i to z Niemiec płynęły silne inicjatywy związane z "filmową Europą”[31]. Idea ta wygasała jednak w latach trzydziestych z przyczyn politycznych oraz w wyniku wprowadzenia dźwięku do filmu, co spowodowało głęboki kryzys niemieckiego przemysłu filmowego w latach 1929-1932 [32]. Spadła wtedy radykalnie liczba przedsiębiorstw, a to zaś wpływało na podejmowanie przez niemieckich filmowców zatrudnienia w ramach zagranicznych inicjatyw, takich na przykład jak film Józefa Lejtesa, który może stanowić przykład spóźnionego oddziaływania koncepcji „filmowej Europy”.

Warto zarazem zaznaczyć, że wraz ze zmianami politycznymi i prowadzeniem nazistowskiej polityki protekcjonizmu wobec rodzimego przemysłu oraz ekspansji gospodarczej, zamierzoną taktyką było przejęcie innych rynków „przez podbój, a nie współpracę”[33]. Jednakże na przełomie 1932 i 1933 roku prowadzono starania o zawarcie umowy z Polską, jeszcze w ramach strategii tak zwanej „miękkiej siły”, opartej na pokojowej retoryce, która miała zapewnić Niemcom hegemonię w kreowanej przez nich koalicji kulturowej[34]. 25 maja 1934 roku zawarto półoficjalne porozumienie, a sfinalizowanie umowy, mimo protestów wielu środowisk, nie tylko żydowskich, miało ostatecznie miejsce 22 grudnia $1937 \mathrm{roku}[35]$. Celem zmian w kinematografii niemieckiej po dojściu Adolfa Hitlera do władzy było całkowite usunięcie Żydów z przemysłu filmowego Rzeszy. Kinematografię nadzorował minister propagandy Joseph Goebbels. 1 lipca 1933 roku powstała Izba Filmowa, która miała zrzeszać wyłącznie aryjskich przedstawicieli środowiska filmowego (od wtedy „nie wolno było zatrudniać w kinematografii «niearyjczyków» i osób związanych małżeństwem z Żydami”), a 22 września - Izba Kultury Rzeszy[36]. Migracje żydowskich filmowców nie były jednak w owym okresie jeszcze bardzo popularne[37]. Intrygująca jest zaś w tym kontekście podjęta przez Franza Weihmayra wiosną 1933 roku decyzja o ponownej współpracy z reżyserem żydowskim z Polski i zaangażowaniu się w projekt, który związany był wprost z tematyką aliji.

s. 57; L. Armatys, W. Stradomski, Historia filmu polskiego, t. 2, Warszawa 1988, s. 137.

[31] Zob. K. Thompson, op.cit., s. 28-29 i 41.

[32] Zob. ibidem, s. 32 i 41.

[33] Ibidem, s. 44.

[34] Należy przypomnieć, że 26 stycznia 1934 roku Polska i Rzesza zawarły pakt o nieagresji. Zob. K. Pryt, Polskie elementy w nazistowskiej polityce filmowej 1933-1939, „Pleograf. Kwartalnik Akademii Polskiego Filmu" 2019, nr 1, <http://akademiapolskiegofilmu.pl/pl/historia-polskiego-filmu/pleograf/kino-przedwojenne/16/polskie-elementy-w-nazistowskiej-polityce-filmowej-1933-1939/668>, dostęp: 12.03.2020. [35] Zob. ibidem.

[36] B. Drewniak, Teatr i film III Rzeszy. W systemie hitlerowskiej propagandy, Gdańsk 2011, s. 179. Skutki zmian w kinematografii Rzeszy odnosiły się także do filmowców z innych krajów (Juliusz Gardan ze względu na żydowskie pochodzenie nie mógł wziąć udziału w berlińskiej premierze swojego filmu, zdjęto też z niemieckich ekranów ze względu na żydowskie pochodzenie reżysera film Młody las Józefa Lejtesa). Zob. K. Pryt, op.cit.

[37] Sabine Hake przypomina, że początkowo niearyjscy reżyserzy i producenci mogli jeszcze kontynuować prace podlegające regulacjom filmowego importu i obcych firm, ale warunki te były arbitralne i nieprzewidywalne. Część żydowskich filmowców kontynuowała też pracę, na mocy indywidualnych decyzji Goebbelsa, które nie miały jednak żadnych wiążących reguł. Zob. eadem, Popular Cinema of the Third Reich, Austin 2001, s. 27-30. 
Jako operator przez ponad pół roku towarzyszył on z kamerą Aleksandrowi Fordowi i jego żonie Oldze w Palestynie[38]. Zgodnie z zamysłem producenta Władysława Markiewicza młody reżyser z kręgu START-u, którego Legion ulicy został przez krytykę w Polsce doceniony, miał zebrać materiał dokumentalny na temat życia osadników żydowskich, a także zrealizować projekt filmu fabularnego, który propagowałby ideę syjonistyczną[39]. Aleksander Ford nie był jednak jej zwolennikiem, nie eksponował też swojej żydowskiej tożsamości[40]. Jego lewicowe poglądy stały się natomiast bodźcem do stworzenia zarysu fabuły, dla której ideologiczną kanwą był raczej internacjonalizm, międzyludzka solidarność i klasowe braterstwo robotników[41]. Wspomniane okoliczności, w kontekście pracy niemieckiego operatora nad materiałem filmowym, który złożył się na dokumentalną Kronikę palestyńską oraz fabularno-dokumentalny film dźwiękowy Chalutzim, prowokują pytanie o motywację związaną z jego udziałem w ekipie filmowej Aleksandra Forda[42]. Efekty palestyńskiej peregrynacji Weihmayra z kamerą, $\mathrm{w}$ drugim wariancie, a więc syjonistycznym, a nie lewicowym (ponieważ producent przemontował materiał i wprowadził zakończenie, którego wymowa jednoznacznie wpisywała się w ekranową wizję powrotu do Erec Israel), nie musiały w III Rzeszy budzić zastrzeżeń, ponieważ kwestia wymuszania na Żydach emigracji wpisana była w program nazistowskiej partii[43]. Warto zaznaczyć, że film powstał w okresie, gdy „naziści z ministerstwa gospodarki i syjoniści z Agencji Żydowskiej zawarli nieoczekiwane porozumienie zwane «transferem», które przewidywało wspólne wspieranie alija bet (zorganizowanej nielegalnie imigracji Żydów do Palestyny)"[44]. Naziści dostrzegali w niej oczywiście możliwości pozbycia się z państwa niechcianych obywateli.

Należy podkreślić, że na kluczową dla filmu Chalutzim przestrzeń symboliczną składają się opozycyjne motywy - rozległej pustyni oraz krainy bujnych upraw i rozwijających się miast (ukazanej w dokrętkach), a także kategoria spacjalna[45], pełniąca funkcję po-

[38] Zob. N. Gross, Film żydowski w Polsce, przeł. A. Ćwiakowska, Kraków 2002, s. 50; M. Danielewicz, Ford reżyser, Warszawa 2019, s. 67-70; T. Rachwald, "Aleksander Ford” człowiek zmyślony. Tożsamość i polityka $w$ Sabrze (1933) $i$ Drodze młodych (1936), „Kwartalnik Filmowy” 2015, nr 92, s. 64; J. Preizner, Aleksander Ford - car PRL-owskiego kina, [w:] Autorzy kina polskiego, (t. 2), red. G. Stachówna, B. Zmudziński, Kraków 2007.

[39] Zob. N. Gross, op.cit., s. 49. Por. M. Danielewicz, op.cit., s. 67; T. Rachwald, op.cit., s. 64-67.

[40] Zob. T. Rachwald, op.cit., s. 61-74.

[41] Zob. ibidem, s. 65-66.

[42] Zob. N. Gross, op.cit., s. 150.

[43] Zob. T.M. Korczyński, Kiedy dom zaczyna płonać. Swój, obcy, wróg w Trzeciej Rzeszy z perspektywy konstruktywistycznej socjologii wiedzy, Gdańsk 2019, s. 313.
[44] Ibidem, s. 314. Na mocy umowy, obowiązującej do 3 września 1939 roku, instytucja Trust and Transfer Office Haavara Ltd. działająca w Tel Awiwie zorganizowała migracje 55 tysięcy Żydów do Palestyny. Zob. ibidem; A. Patek, Żydzi w drodze do Palestyny 1934-1945. Szkice z dziejów aliji bet nielegalnej imigracji żydowskiej, Kraków 2009, s. 125.

[45] Odwołuję się do terminu pochodzącego od łac. słowa spatium - oznaczającego przestrzeń, który stosowany jest w literaturoznawstwie i badaniach kulturoznawczych, służąc doprecyzowaniu zagadnień związanych z problematyką przestrzeni. Szczególnie istotny, w kontekście podejmowanych w tym artykule analiz, jest fakt, że wspomniane badania mogą uwzględniać parametry, które wpływają na kształt przestrzeni, mając charakter polityczny, historyczny, społeczny i kulturowy. Warto zaznaczyć, że otwarcie 
średnika pomiędzy wspomnianymi elementami, czyli kopana przez osadników studnia wraz z motywem wody, przypisanym tego typu wyobrażeniom. Pustynne pustkowie, jako obszar nienadający się do życia, staje się w tym filmie, zgodnie ze światopoglądowo motywowaną koncepcją reżysera, miejscem ciężkiej pracy, wspólnych zmagań grupy osadników z naturą i losem (w czym leży również podobieństwo fabuły z filmem Julija Rajzmana Ziemia pragnie z 1930 roku) [46]. Wykreowane przez Franza Weihmayra ekranowe wyobrażenie pustyni nie nawiązuje bezpośrednio do motywowanych religijnie sensów, a więc obszaru mającego walor miejsca objawiającego Boga, otwartego na transcendencję, symbolu ascetycznej duchowości[47]. Kontekst religijny pojawia się w filmie Chalutzim jedynie w krytycznym ujęciu - w postaci scen ukazujących derwisza oddającego się ekstatycznym tańcom podczas modlitw o deszcz wznoszonych przez Arabów[48]. Nieracjonalność zachowań tubylczej ludności kontrastowana jest, dzięki montażowi naprzemiennemu, z obrazami osadników wytrwale budujących studnię. Znamienne jednak, że, zgodnie z pierwotną realizatorską koncepcją filmu, etniczność pionierów nie jest podkreślana; we wstępie są oni nazywani młodymi entuzjastami, rozmawiają ze sobą po polsku, a jedynym śladem ich żydowskiego pochodzenia są pieśni śpiewane po hebrajsku. Fabuła, zgodnie z poglądami politycznymi Aleksandra Forda, eksponuje problemy wynikające $\mathrm{z}$ różnic klasowych, a nie narodowościowych (jej wymowa zbliża się też do idei internacjonalizmu, o czym świadczą sceny ukazujące wydobycie wody). Tłem napaści ludności arabskiej na osadników są zaś bazujące na religijnym fanatyzmie knowania szejka, które wynikają ze stosunków własności, gdyż to do niego należą okoliczne pola oraz jedyna działająca studnia.

Ciężar znaczeniowy obrazów surowego pustynnego krajobrazu i budowanej przez osadników studni, jako „symbolu wzniosłych aspiracji" [49] człowieka pozwala więc na wydobycie aspektu wspólnotowego (nieokreślonego etnicznie) altruistycznego działania ludzkiego w surowych, niesprzyjających warunkach przyrodniczych. Jednakże dodany przez producenta, bez udziału reżysera, finał filmowej opowieści zmienia jej wymowę. Zgodnie z koncepcją zamierzoną przez Aleksandra Forda miała być ona „osadniczą tragedią" [50] (co akcentował wątek śmierci zakochanej pary Arabki i Żyda podczas napaści

refleksji teoretycznoliterackiej na kulturowe konteksty, a w szczególności na dyskurs geograficzny, reprezentuje w rodzimym literaturoznawstwie na przykład Elżbieta Rybicka, zainspirowana interdyscyplinarną koncepcją geokrytyki Bertranda Westphala, której przedmiotem są interakcje pomiędzy przestrzeniami geograficznymi a ich reprezentacjami w literaturze, sztuce, fotografii czy filmie. Zob. E. Rybicka, Geopoetyka. Przestrzeń i miejsce we współczesnych teoriach i praktykach literackich, Kraków 2014; eadem, Geopoetka, geokrytyka, geokulturologia. Analiza porównawcza pojęć, „Białostockie Studia Literaturoznawcze" 2011, nr 2, s. 34-35; Od poetyki przestrzeni do geopoetyki, red. E. Konończuk, E. Sidoruk, Białystok 2012, s. 11-26.

[46] Zob. T. Rachwald, op.cit., s. 65, 67.

[47] Zob. J.E. Cirlot, Pustynia, [w:] idem, op.cit., s. $342-343$.

[48] Por. T. Rachwald, op.cit., s. 66.

[49] J.E. Cirlot, Studnia, [w:] idem, op.cit., s. 342-343.

[50] Por. T. Rachwald, op.cit., s. 66. 
na osadników oraz zasypania budowanej studni przez pustynny wiatr) i stanowić przestrogę, przekonując widzów do sensu międzyludzkiego, ponadnarodowego braterstwa i solidarności. Natomiast ukazane w finale Chalutzim obrazy krainy bujnych upraw oraz rozwijających się miast i zakładów produkcyjnych, wzmocnione słownym komentarzem o dokonaniach pionierów, mają przekonywać, że ich trud (zobrazowany w sekwencjach usuwania kamieni z piaszczystego pola oraz mozolnego kopania studni) nie pozostanie daremny, a pustynne tereny Palestyny mogą zostać zagospodarowane dla dobra jej mieszkańców. Są to wizje nawiązujące znaczeniowo do symboliki „ziemi obiecanej”[51] - ojczyzny dającej szansę rozwoju żydowskim przybyszom z Europy, które, wbrew intencjom reżysera, wprowadzają odniesienia religijne, biblijne. Neutralizują one też zarazem kosmopolityczny, ponadnarodowy sens działań osadników, który wyrażają sceny euforycznej radości dzielonej przez Żydów i biedną ludność arabską w związku z ostatecznym pojawieniem się w studni życiodajnej wody.

Należy zaznaczyć, że zanim Sabra miała w Polsce premierę 21 listopada 1933 roku, Franz Weihmayr stanął za kamerą, realizując wraz z czterema innymi operatorami pod kierunkiem Leni Riefenstahl, w trakcie V zjazdu NSDAP w Norymberdze, trwającego od 30 sierpnia do 3 września 1933 roku, zdjęcia do dokumentu zatytułowanego Der Sieg des Glaubens (Zwycięstwo wiary) [52]. Został on także we wrześniu tego samego roku operatorem propagandowego fabularnego obrazu heroizującego postać Horsta Weselli, który reżyserował Franz Wenzler[53]. Udział tego operatora w produkcjach filmowych stanowiących ostentacyjny wyraz nazistowskiej propagandy nie musiał jednak przynieść jednoznacznie pozytywnych dla niego skutków, ponieważ po zamkniętym pokazie 6 października 1933 roku, w związku z decyzją ministra propagandy i informacji, film Wenzlera został skierowany do przemontowania pod zmienionym tytułem, a dokument Leni Riefenstahl również wzbudzał pewne kontrowersje[54]. W tym okresie nastąpił też ważny zwrot w życiu osobistym Franza Weihmayra - rozwód z Adą Tsechową, córką prominentnej gwiazdy kina niemieckiego, kochanki Josepha Goebbelsa - Olgi Tsechowej[55]. Wpływy w środowisku fil-

[51] Zob. J.E. Cirlot, Ziemia obiecana, [w:] idem, op.cit., s. 474.

[52] Zob. S. Brockmann, A Critical History of German Film, Rochester 2010, s. 154-159.

[53] Zob. B. Drewniak, op.cit., s. 304-305; A. Gwóźdź, Zaklinanie rzeczywistości. Filmy niemieckie $i$ ich historie 1933-1949, Wrocław 2018, s. 49-52. Franz Weihmayr pracował też od września do listopada 1933 roku przy realizacji niemieckiej wersji Wilhelma Tella, kręconego na zlecenie sympatyzującego z nazistami producenta szwajcarskiego Ralpha Scotoniego. [54] Film Wenzlera wprowadzał wprost na ekran wątek SA, a Goebbels przekonany był, że miejscem oddziaływania SA nie jest kino, lecz ulica. Nie przepa- dał on też za dokumentalistką, a uwieczniony w jej filmie wizerunek Ernsta Röhma spowodował, że po tak zwanej „nocy długich noży” nakazano zniszczyć jego kopie. Zob. A. Gwóźdź, op.cit., s. 49-52; T. Kłys, op.cit., s. 104; S. Brockmann, op.cit., s. 157.

[55] Ojcem jej był pierwszy mąż Olgi - Michaił Tsechow, krewny Antoniego Czechowa. Ada, o trzynaście lat młodsza od Franza Weihmayra, po rozwodzie poślubiła Wilhelma Rusta. Zob. A. Gwóźdź, op.cit., s. 38; R. Helker, Die Tschechows. Wege in die Moderne, Berlin 2005; R. Helker, C. Lenssen, Der Tschechow-Clan. Die Geschichte einer deutsch-russischen Künstlerfamilie, Berlin 2001, s. 162, 224. 
mowym III Rzeszy teściowej operatora mogły pomagać mu w rozwoju kariery. Ważną rolę odegrała także znajomość z Carlem Froelichem, który był członkiem NSDAP, w 1939 roku Hitler nadał mu tytuł profesora, a Goebbels powołał na prezydenta Izby Filmowej Rzeszy[56]. W koncernie UFA Franz Weihmayr należał do jego najważniejszych współpracowników. W 1934 roku zaś ulubienica Adolfa Hitlera Leni Riefenstahl zaangażowała ponownie tego operatora do realizacji swojego kolejnego dokumentu poświęconego Führerowi i NSDAP Triumph des Willens (Triumf woli), który miał przyćmić jej poprzednie dzieło[57]. Jednakże w kolejnych dwóch latach nastąpił w karierze Franza Weihmayra odwrót od filmowych przedsięwzięć związanych w otwarty sposób z ideologią nazistowską. Nie podjął on już więcej współpracy z Leni Riefenstahl, zrezygnował z kręcenia dokumentów i zajął się wyłącznie produkcjami fabularnymi, w konwencji filmu muzycznego, kostiumowego, przygodowego i melodramatu[58]. Filmy zrealizowane przez niego ówcześnie w Anglii z Reginaldem Denhamem to musical i komedia grozy [59]. Warto podkreślić, że w tym czasie część reprezentantów niemieckiego środowiska filmowego wybierała ze względów politycznych emigrację, między innymi do Wielkiej Brytanii i Stanów Zjednoczonych (na przykład Leontine Sagan, Ludwig Berger)[60]. W latach 1935-1937 rozwijała się także współpraca Franza Weihmayra z dwoma reżyserami niemieckimi, którzy niebawem zdecydowali się także wyjechać z kraju. W 1935 roku nakręcił on z Frankiem Wysbarem fantastyczną opowieść Fährmann Maria, nawiązującą do alegorycznej stylistyki niemego kina weimarskiego[61]. Pracował też z Detlefem Sierckiem podczas realizacji jego ostatnich niemieckich produkcji[62]. Filmy Zu neuen Ufern (Do nowych brzegów) i La Habanera okazały się szczególnie ważne ze względu na dalszy rozwój kariery operatora. Wyniosły one do roli gwiazdy zatrudnioną przez UFA w 1936 roku szwedzką aktorkę Zarah Leander[63]. Miała ona konkurować z robiącą karierę w Hollywood Gretą Garbo i zastąpić Marlenę Dietrich, która wyemigrowała do Stanów Zjednoczonych[64]. Zdjęcia autorstwa Franza Weihmayra, który stał się stałym operatorem Zarah Leander, wywarły ogromny wpływ na ukształtowanie ekranowego wizerunku tej aktorki[65]. Jako filmowa gwiazda III Rzeszy uczestniczyła ona wraz

[56] Zob. B. Drewniak, op.cit., s. 216, 390.

[57] Zob. A. Gwóźdź, op.cit., s. 91-94.

[58] Były to Das Hofkonzert, reż. D. Sierck, z Márthą Eggerth; Stjenka Rasin (Volga-Volga), reż. A. Volkoff; Moscow-Shanghai, reż. P. Wegener, z Polą Negri. Scenariusze do tych filmów stworzył Kurt Heynicke.

[59] Calling the Tune (1936); The House of the Spaniard (1936).

[60] Zob. S. Hake, op.cit.

[61] Andrzej Gwóźdź dostrzega w strukturze tego obrazu analogie do ideologii „kwi i ziemi” (idem, op.cit., s. 99). Por. T. Kłys, op.cit., s. 136.
[62] Detlef Sierck, podobnie jak Frank Wysbar, którego żona była Żydówką, zdecydował się na emigrację do Stanów Zjednoczonych, gdzie zmienił nazwisko na Douglas Sirk i pracował jako filmowiec. Jego amerykańskie melodramaty doceniła krytyka lat 70. Zob. T. Ryan, The Films of Douglas Sirk. Exquisite Ironies and Magnificent Obsessions, Jackson 2019; B. Klinger, Melodrama and Meaning: History, Culture, and the Films of Douglas Sirk, Bloomington 1994.

[63] Zob. K. Kreimeier, op.cit., s. 299, 317, 346, 354; J.F. Bruns, op.cit., s. 127, 136.

[64] Zob. S. Brockmann, op.cit., s. 173. [65] Zob. J.F. Bruns, op.cit., s. 130. 
ze swoim operatorem w projektach, które wpisywały się najczęściej w formułę miękkiej nazistowskiej propagandy.

Film La Habanera jest zaś produkcją, która prowokuje badaczy do formułowania ambiwalentnych interpretacji i ocen; o jej niejednoznaczności pisał Tim Bergfelder, wskazując na obecne w niej elementy eurocentrycznych fantazji i wyobrażeń związanych z ideologią nazistowską, które jednak, ze względu na wpisane w strukturę narracyjną elipsy, ambiwalencje, odczytać można również jako ironię i dwuznaczność[66]. W fabule, której zasadnicza część rozgrywa się w Portoryko, dokąd wraz ze swoją ciotką przybywa młoda Szwedka Astrée, pragnąca doświadczać egzotycznego świata i namiętności, zaznaczają się wyraźnie przejawy dyskursu kolonialnego, przede wszystkim w postaci tendencji do stereotypizacji w sposobie ukazania tubylców (na przykład sekwencja oglądania przez Astrée i jej ciotkę pokazu lokalnej corridy, wydobywa kontrast między dystyngowanymi przedstawicielkami „cywilizowanej” Północy a reagującymi żywiołowo, hałaśliwymi wyspiarzami). Prosta, biedna egzystencja mieszkańców wyspy znajduje jednak uzasadnienie w stosunkach społecznych, ukazanych z pewną dozą krytycyzmu[67]. Narzucający się widzowi La Habanery fabularny mechanizm zderzania ze sobą kreacji zdystansowanych, racjonalnych postaci reprezentantów Skandynawii i impulsywnych, skorumpowanych, skłonnych do przesadnych reakcji, obyczajowo swobodnych i erotycznie roznamiętnionych mieszkańców Karaibów, jest jednak zarazem kwestionowany, dzięki wyraziście kosmopolitycznej postawie wpisanej w konstrukcję postaci Astrée. Reżyser sygnalizuje więc dystans do otwarcie rasistowskich poglądów głoszonych przez karykaturalnie zaprezentowaną postać antypatycznej ciotki, właśnie poprzez reprezentowaną przez główną bohaterkę i deklarowaną przez nią wprost postawę otwartości na to, co obce. Jej zauroczenie lokalnym właścicielem ziemskim - torreadorem Don Pedro de Avila - i ślub z nim skutkują zamieszkaniem Astrée na wyspie, która urzeka ją swą przyrodą i klimatem, pociąga egzotyczną kulturą. Historia małżeństwa, które czyni bohaterkę nieszczęśliwą u boku apodyktycznego, zazdrosnego męża, może być jednak zarazem odczytywana w duchu germańskiej propagandy, jako przestroga przed wiązaniem się przez kobietę z Północy z przedstawicielem Południa[68]. Sprzeczności, które zaznaczają się w La Habanerze, wynikają z faktu, że w postaci Astrée obecna jest zarówno nostalgia za rodzinnymi stronami, jak i tęsknota za obcym, innym światem, rządzonym przez odmienne reguły i wartości, a także silne pragnienie doświadczania kosmopolitycznego, ponadnarodowego uczucia, „wywrotowego pożądania” Innego[69]. Finałowa sekwencja,

[66] Zob. T. Bergfelder, op.cit., s. 65-71. Andrzej Gwóźdź zaznacza, że film ma dyskretne antyrasistowskie przesłanie. Zob. idem, op.cit., s. 74.

[67] Zob. J. Holliday, op.cit.

[68] Andrzej Gwóźdź zwraca uwagę w tym kontekście, że słowo oznaczające narodowość w zdaniu wypowiedzianym przez rodaka bohaterki doktora Nagela: „Wszystko w Pani synu jest szwedzkie” może budzić skojarzenie z określeniem aryjskie (idem, op.cit., s. 75. Por. T. Kłys, op.cit., s. 130).

[69] T. Bergfelder, op.cit., s. 64. 
w której Astrée, opuszczając wyspę, spogląda na nią tęsknie po raz ostatni, niesie więc przesłanie, że marzenie o egzystencji „obywatelki świata" w egzotycznym, obcym etnicznie otoczeniu, ma swoje miejsce w sferze pragnień niezaspokojonych, gdyż ukazane w filmie realia podkopują wiarę w jego ziszczenie[70].

Przestrzeń symboliczna w La Habanerze ufundowana jest zaś na ekranowych obrazach wyspy, wraz z wpisanymi w tę strukturę porządkami - publicznym i prywatnym, w kontekście krzyżujących się również w fabule wątków romansowych z motywem przewodnim kosmopolitycznego uczucia oraz elementów sensacyjnych, powiązanych z kategoriami narodowymi, etnicznymi. „Rajska” wyspa z jej bujną przyrodą, malowniczymi krajobrazami oraz przejawami egzotycznej kultury wyspiarzy (budynki, stroje bogate w ozdoby, proste zajęcia mieszkańców) jest konwencjonalną scenerią dla romansu, ale zarazem stanowi ona symboliczną przestrzeń, opartą na złożonych kontekstach znaczeniowych. Możliwe jest więc postrzeganie jej, w myśl jungowskiej interpretacji, jako „schronienia przed groźnym atakiem nieświadomego"[71] i swoistego punktu objawiającego "metafizyczną moc”[72], w kontekście doświadczanej przez główną bohaterkę niewypowiedzianej tęsknoty oraz niezaspokojonego pragnienia wolności od sztywnych zasad, narzuconych przez rodzimą skandynawską kulturę. Wyspa jest zarazem symbolem izolacji, samotności i śmierci, gdyż dotykająca jej mieszkańców portorykańska gorączka zbiera śmiertelne żniwo[73]. Znaczenie to łączy się również z wątkiem narzuconego przez męża, zarówno samej Astrée, jak i ich synowi, odseparowania od szwedzkich korzeni małżonki. Symbolizują to wyraźnie skontrastowane obrazy bezpiecznej przestrzeni, którą stanowi salon w Sztokholmie, z malowniczym pejzażem $\mathrm{w}$ śniegu za oknem oraz filmowe wizje egzystencji bohaterki, odizolowanej od zewnętrznego otoczenia za murami i żaluzjami, w dusznych wnętrzach domu Don Pedra.

Konwencjonalne obrazowanie wpisane w sztafaż egzotycznego melodramatu - bogatej, otoczonej ogrodem willi - poddane zabiegowi personalizacji, odzwierciedla więc mentalne uwięzienie bohaterki, zmuszonej do egzystencji w domu zazdrosnego męża. Rajska, rozgrzana słońcem wyspa staje się „piekłem” [74] i przekleństwem, a piękny dom więzieniem i w konsekwencji epidemii także miejscem śmierci małżonka. Przestrzeń symboliczna La Habanery wydobywa więc właśnie sprzeczności i dualizm. Ekranowe wizje wyspy oraz usytuowanego na niej domu Don Pedra oparte są na strategii kontrastowania początkowych i późniejszych ujęć. Obrazy stanowiące ekspozycję zdominowane są przez rozświetloną słonecznymi promieniami bujność egzotycznego krajobrazu oraz malowniczość bogatego domostwa, jako pewnej fasady, zza której w dalszej części fabuły wyłaniają się przygnębiające, ukaza-

[70] Por. ibidem, s. 66.

[71] J.E. Cirlot, Wyspa, [w:] idem, op.cit., s. 465.

[72] Ibidem.

[73] Zob. ibidem.
[74] Kwestię tę, zakończoną twierdzeniem, że nie żałuje, bohaterka wypowiada w finale filmu w scenie odpływania statkiem z Portoryko. 
ne $\mathrm{w}$ półcieniu obrazy wnętrz i miejsc powiązanych $\mathrm{z}$ dramatycznie rozwijającym się wątkiem epidemii, która dziesiątkuje mieszkańców. Owo dualistyczne waloryzowanie ekranowej przestrzeni pozwala też na zderzenie wątku reprezentowanej przez Astrée kosmopolitycznej ciekawości barwnego świata i egzotycznej kultury, jej tęsknoty za swobodą i namiętnością, które przywiodły ją do Portoryko, z krytyczną wizją opartych na korupcji realiów wyspiarskich, z wpisaną w nie biedną egzystencją tubylców, którym zagraża śmierć z powodu rozwijającej się w upale epidemii. La Habanera nie niesie jednoznacznego przesłania, pozostaje ono zawieszone między idealistycznymi pragnieniami bohaterki a rzeczywistością warunkowaną przez kolonialny dyskurs. Klamrowym motywem spacjalnym, powiązanym z symboliczną przestrzenią wyspy, jest zaś statek, jako środek, dzięki któremu Astrée przybywa do Portoryko, ale także może je opuścić, wracając do ojczyzny przepełniona niespełnioną uczuciową tęsknotą.

La Habanera jest filmem symptomatycznym dla strategii ucieczki od rzeczywistości w melodramatyczną konwencję narracyjną i w egzotyczny entourage. Należy przypomnieć, że po roku 1933 powszechne były próby przystosowania się przedstawicieli niemieckiego środowiska filmowego do politycznych uwarunkowań poprzez adaptację struktur kina rozrywkowego, jako wytwarzającego populistyczne iluzje[75]. Tej strategii Franz Weihmayr, jako operator, pozostał wierny także po wybuchu II wojny światowej, konsekwentnie biorąc udział w projektach filmowych, które wpisywały się w formułę ekranowej rozrywki w III Rzeszy, a więc form eskapizmu pozwalającego na odwrócenie uwagi od kontrowersyjnych kwestii, jak również podtrzymanie dobrych nastrojów wśród obywateli[76]. Kino to znamionowało więc swoiste rozszczepienie. Filmy rozrywkowe, zawierające dyskretny ładunek nazistowskiej ideologii, stanowiły znaczącą część produkcji kinematografii tego okresu. Wspomniany zaś syndrom eskapizmu łączył się z regułą przyjemności, na której rzecz działał również, kreowany z sukcesem przez Franza Weihmayra, ekranowy wizerunek Zarah Leander. Wierzyła ona, że uda jej się utrzymać z dala od polityki, jednak jako gwiazda kina III Rzeszy funkcjonowała w ramach aparatu wszechogarniającej propagandy[77].

Kręcony jesienią 1941 i w marcu 1942 roku film Wielka miłość prezentował wizje, które nawiązywały wprost do opartego na militarnej ekspansji porządku nazistowskiego i służyły jego legitymizacji (taką funkcję pełniły zarówno sceny w okupowanym Paryżu, jak i wyko-

[75] Zob. R. Grunberger, Historia społeczna Trzeciej Rzeszy, przel. W. Kalinowski, Warszawa 1994, s. 453, 461; A. Gwóźdź, op.cit., s. 188-189; L. Schulte-Sasse, Entertaining the Third Reich. Illusions of Wholeness in Nazi Cinema, Durham 1996; A.K. Porter, E. Rentschler, op.cit.

[76] Zob. B. Drewniak, op.cit., s. 328; T. Kłys, op.cit., s. $118-133$.
[77] Niewywiązywanie się UFA z finansowej umowy i coraz intensywniejsze naloty skłoniły gwiazdę do powrotu do Szwecji jeszcze przed premierą filmu Damals w marcu 1943 roku. Andrzej Gwóźdź przypomina, że jej odmowa przyjęcia obywatelstwa niemieckiego doprowadziła też ostatecznie do konfliktu z Goebbelsem. Zob. idem, op.cit., s. 182. 
rzystane w filmie wojenne kroniki). Pozornie II wojna światowa może wydawać się jedynie tłem dla romansu, jednakże to właśnie konstytutywny dla ideologii nazistowskiej obowiązek niemieckiego obywatela względem Rzeszy wysuwa się na pierwszy plan jako przesłanie wspomnianego filmu Rolfa Hansena. Jego egzemplifikacji służy nie tylko melodramatyczna fabuła, oparta na regułach damsko-męskiej gry uczuć, której perypetie pozwoliły na ukazanie procesu przemiany Hanny Holberg - duńskiej gwiazdy berlińskiej rewii zakochanej z wzajemnością w Paulu, oficerze Luftwaffe, polegającej na jej stopniowym dojrzewaniu do przyjęcia ofiarnej wobec ojczyzny postawy ukochanego jako własnej. Rozmywa się przy tym kontekst jej tożsamości narodowej, ponieważ dla gwiazdy rewii to Berlin jest domem. Pozornie więc kosmopolityczne uczucie zostaje, zgodnie z ideologiczną wymową Wielkiej miłości, przetransponowane w historię rozkwitającej w czasie wojny miłości nordyckiej pary, a więc związku, w którym, w oparciu o patriarchalny porządek, to Paul, jako Niemiec i lotnik, a więc reprezentant elity Rzeszy, wywiera wpływ na postawę Hanny. Jako jego narzeczona, doświadczając solidarnie tego, czego doznają niemieckie kobiety czekające na mężów walczących na froncie, staje się ona częścią narodowej wspólnoty. Ekranowe obrazy życia mieszkańców Berlina służyły również przesłaniu filmu o germańskiej narodowej sile, jedności obywateli III Rzeszy i ich powszechnej gotowości do ponoszenia koniecznych wyrzeczeń w związku z prowadzoną wojną. Były to, jak zauważa Stephen Brockmann, oddziałujące mobilizująco projekcje rzutowane na świadomość odbiorców[78]. Wielka miłość stanowi więc sztandarowy przykład propagandowego filmu rozwijającego motywy związane $\mathrm{z}$ ideą frontu domowego oraz rolą kobiet niemieckich i ich powinnościami względem nazistowskiego państwa[79].

Zgodnie z obowiązującymi w III Rzeszy wyznacznikami rozrywki filmy realizowane w czasie II wojny światowej służyć miały podbudowaniu morale narodu, ale i odprężeniu obywateli. Stąd też zaznaczające się w kreacji przestrzeni diegetycznej Wielkiej miłości swoiste niekoherencje, jak i wizualne cliché. Sztampowo sfotografowane bogate wnętrza domów, hoteli i restauracji, scenografia rewiowej sceny, malownicze rzymskie i paryskie widoki, północnoafrykańskie plenery jako elementy wpisujące się w zakorzenione w gatunku melodramatu i filmu muzycznego czynniki estetycznej ładności i dostatku (podkreślane również kreacjami Hanny jako muzycznej gwiazdy) miały także swoją propagandową wymowę, współkreując wizerunek zwycięskich, silnych, dostatnich Niemiec. Piwnica berlińskiego domu, w którym mieszka Hanna, służąca mieszkańcom jako przeciwlotniczy schron,

[78] Zob. S. Brockmann, op.cit., s. 170.

[79] Por. A. Gwóźdź, op.cit., s. 180; R. Grunberger, op.cit., s. 463; S. Brockmann, op.cit., s. 172, 178. Film daje przegląd tego typu tematów, nie pojawiają się w nim jedynie motywy antysemickie. Warto zaznaczyć, że w 1938 roku Franz Weihmayr nakręcił film w reżyserii Roberta A. Stemmle Am seidenen Faden, oparty na scenariuszu reżysera i Eberharda Froweina, eksploatującym wątki antysemickie. Zagrał w nim Karl Kuhlmann, aktor, który wystąpił też w propagandowym filmie o Rotszyldach. Zob. K. Kreimeier, op.cit. 
ze względu na zobrazowane zachowania lokatorów zgromadzonych w niej podczas alarmu (granie w gry, szydełkowanie, śpiewanie piosenek i dzielenie się resztkami kawy), przekształca się w swoisty salon towarzyski. Sekwencja ta wpisuje się w bazowy dla struktury Wielkiej miłości czynnik lekkiej, przyjemnej, komercyjnej rozrywki, pozostając zarazem obrazowym ekwiwalentem ideologicznej wizji niezłomnej narodowej wspólnoty, której członkowie są solidarni i udzielają sobie bratniej pomocy. Propaganda nazistowska i element rozrywki symbiotycznie współistnieją w Wielkiej miłości Rolfa Hansena, którą (podobnie jak Koncert życzeń, nakręcony także przez Franza Weihmayra $\mathrm{w}$ konwencji wojennej rewii z elementami melodramatu) obejrzało 27 milionów widzów[80].

Należy podkreślić, że na przestrzeń symboliczną filmu składają się wyobrażenia spacjalne związane $\mathrm{z}$ dwoma dopełniającymi się i fabularnie powiązanymi, zespołami elementów. Pierwszym z nich jest konstruowany w szczególny sposób ekranowy wizerunek stolicy III Rzeszy. Dominują ujęcia wnętrz - apartamentów, klatek schodowych, restauracji, kina, rewiowej sali, garderoby (nacechowanych w nawiązaniu do wspomnianych już dwóch czynników), a także środków komunikacji (scena w tramwaju i w U-Bahnie), unikano zaś prezentowania przestrzeni urbanistycznej. Znaczący jest właśnie ów brak, szczególnie na tle wspomnianych ujęć Paryża i Rzymu. Kluczem do zrozumienia strategii kreacji przestrzeni diegetycznej stolicy Rzeszy są zaś dwa znaczące ujęcia, w których pojawia się ten sam rozpoznawalny dla widzów budynek. Jest to siedziba Ministerstwa Lotnictwa III Rzeszy, przed którą Paul rozmawia ze swym towarzyszem w początkowych scenach filmu. Po raz drugi pojawia się ona jako tło w scenie ukazującej tłum berlińczyków słuchających komunikatu o rozpoczęciu wojny ze Związkiem Radzieckim. Istotną cechą wspomnianego gmachu jest styl wpisujący się w monumentalne architektoniczne koncepcje siedzib nazistowskich urzędów autorstwa Alberta Speera[81]. Ów pojedynczy, zaprezentowany na ekranie obiekt pozwalał, poprzez mechanizm projekcji przestrzeni domyślnej, odsyłać do wyobrażeń propagandowego centrum Rzeszy, które zgodnie z wizją Adolfa Hitlera dotyczącą przyszłych Niemiec po zwycięskiej wojnie (a więc $\mathrm{z}$ tak zwanym planem Germania - Stolica Świata) miało zostać przebudowane pod nazistowskim przewodnictwem i na podstawie architektonicznych projektów wspomnianego Alberta Speera [82]. Zrealizowano w latach 1937-1943 tylko część z nich, wyburzając pod nowe budowle wiele starych budynków, w przekonaniu, że architektura berlińska jest zbyt prowincjonalna i należy stolicy nadać wygląd przewyższający monumentalnością oraz rozmachem inne metropolie europejskie. Zacierano w ten sposób także ślady Berlina epoki Republiki Weimarskiej, jako kosmopolitycznego miasta, mekki dla

[80] Przyniosło to przemysłowi filmowemu III Rzeszy ogromne zyski. Zob. A. Gwóźdź, op.cit., s. 18o; S. Brockmann, op.cit., s. 167; R. Grunberger, op.cit., s. $463-464$.
[81] Zob. V. Knoph, S. Martens, Görings Reich. Selbstinszenierungen in Carinhall, Berlin 2006, s. 207.

[82] Zob. M. Housden, Hitler: Study of a Revolutionary?, Routlege 2000, s. 150. 
artystycznej cyganerii oraz środowisk homoseksualnych[83]. Drugi zaś zespół elementów spacjalnych, współkształtujących przestrzeń symboliczną filmu, stanowi zmilitaryzowana przestrzeń powietrzna, ukazywana przede wszystkim w sekwencjach lotniczych kronik wojennych[84]. Reżyser Wielkiej miłości bazował na wypracowanej już gotowej formule eksploatowanej w kinie III Rzeszy w związku z bardzo popularnym wśród widzów gatunkiem - obrazów o tematyce lotniczej[85].

Oba zespoły spacjalne, współkreujące znaczenia przestrzeni symbolicznej filmu Rolfa Hansena, łączy występujący w nich czynnik technicznego postępu, który, zgodnie z zamysłami Adolfa Hitlera, miał być wykorzystany w służbie ideologii nazistowskiej i prowadzonej przez III Rzeszę wojny[86]. Wizerunek Berlina oparty został na ekranowym zobrazowaniu sprawnie działających środków komunikacji (tramwaj, U-Bahn); urbanistycznych rozwiązań służących ochronie mieszkańców przed alianckimi nalotami (solidne piwnice), jak również instytucji prężnie działającego przemysłu rozrywkowego, jako ważnego nośnika nazistowskiej propagandy (teatr rewiowy, w którym występuje Hanna, kino wyświetlające kronikę wojenną III Rzeszy). Znamienne jest również, że podobieństwo ujęć widoków z berlińskiego okna Hanny oraz z balkonu hotelu w Rzymie, a także stan zadomowienia bohaterów w przestrzeni europejskich metropolii pozwala na wywołanie w widzu przekonania o wszechpanującej Rzeszy, której obywatele wszędzie czują się jak u siebie (takie jest, obok motywu symbolicznego wsparcia udzielanego przez niemieckich cywilów żołnierzom, przesłanie paryskiego koncertu Hanny zorganizowanego dla Wehrmachtu).

Drugi zespół elementów współkreujących przestrzeń symboliczną filmu Hansena, a więc zmilitaryzowany przestwór, w którym toczy się walka $\mathrm{z}$ alianckimi siłami (wątki wojny w Afryce i Front Wschodni), ma związek z nazistowskim kultem lotnictwa i apoteozą służby w Luftwaffe [87]. Został on zaprezentowany w Wielkiej miłości w przeważającej mierze w odwołaniu do materiałów dokumentalnych, mających unaoczniać niezwyciężoność niemieckiej armii. Popularne w kinie III Rzeszy ekranowe wyobrażenia rodzimego nowoczesnego lotnictwa wojskowego nawiązywały do kluczowego w dyskursie propagandowym w czasie II wojny światowej militarystycznego hasła - wunderwaffe, a więc projektów broni zaawansowanej technologicznie o ogromnej sile[88]. Finałowe ujęcie Wielkiej miłości, ukazujące szczęśliwie ocala-

[83] Zob. I. Luba, Berlin. Szalone lata dwudzieste nocne życie i sztuka, Warszawa 2013; R.W. McCormick, Gender and Sexuality in Weimar Modernity. Film, Literature, and "New Objectivity", London 2001. [84] Zob. A. Gwóźdź, op.cit. s. 181.

[85] Zob. ibidem, s. 139. Metodami stosowanymi przez realizatorów tego typu filmów było zarówno włączanie do nich sekwencji dokumentalnych kronik wojennych, jak i rejestracja zdjęć lotniczych z udziałem Luftwaffe. Zob. ibidem, s. 138, 140.
[86] Zob. A. Heywood, op.cit., s. 242.

[87] Pisze o tym obszernie Andrzej Gwóźdź. Zob. idem, op.cit., s. 133.

[88] Były one związane między innymi z pracami nad samolotami o silnikach rakietowych, myśliwcami odrzutowymi, odrzutowymi samolotami rozpoznawczo-bombowymi i samolotami-rakietami. Zob. R. Ford, Tajne bronie III Rzeszy, przeł. P. Butkiewicz, Warszawa 2000; R. Grunberger, op.cit., s. 54. 
łego z katastrofy Paula wpatrującego się wraz z ukochaną w niebo, na którym przelatuje eskadra bojowych samolotów niemieckich, nawiązuje swym przesłaniem właśnie do koncepcji wunderwaffe. Symboliczny obraz, stanowiący apoteozę siły nie tylko Luftwaffe, ale całego nazistowskiego państwa, przekonywać miał widzów o jego rychłym triumfie na wszystkich frontach II wojny świtowej.

Cztery analizowane filmy, nakręcone przez Franza Weihmayra podczas dekady rządów nazistowskich oraz tuż przed dojściem Hitlera do władzy są świadectwem meandryczności wyborów dokonywanych przez tego operatora, w odwołaniu do przeciwstawnych tendencji ideowych, które uwarunkowane były zarówno czynnikami politycznymi, jak i miały związek z mechanizmami produkcyjnymi. Sposoby ukształtowania przestrzeni przedstawionych Dzikich pól, Chalutzim, La Habanery oraz Wielkiej miłości jako nośników znaczeń symbolicznych, potwierdzają związki dwóch spośród wspomnianych filmów z ideą kosmopolityzmu. Ideologia nazistowska, z którą ekranowy flirt Franz Weihmayr rozpoczął jeszcze w 1933 roku, jest bazowym kontekstem dla symbolicznej przestrzeni powstałego w czasie wojny filmu Rolfa Hansena. Swego rodzaju nawiązaniem zaś do elementów przekazu równościowego z filmów Józefa Lejtesa i Aleksandra Forda jest produkcja Detlefa Siercka z 1937 roku. La Habanera stanowi jednak także pod pewnymi względami próbę gry z konwencjami nazistowskiej propagandy, a sposoby ukształtowania jej przestrzeni symbolicznej pozwoliły na próbę wyakcentowania owego dualizmu. Kariera Franza Weihmayra podczas II wojny światowej odzwierciedlała więc proces „dryfowania” w nurcie kina popularnego III Rzeszy na zasadzie naprzemiennego zbliżania się i oddalania od form wpisujących się w otwartą tendencję propagandową. Film Wielka miłość to radykalny przykład serwitutu na rzecz ideologii nazistowskiej. Poprzez powojenne dokonania Franz Weihmayr, jako operator aktywny ponownie od 1948 roku aż do połowy lat sześćdziesiątych, usiłował zatrzeć pamięć o swoim wcześniejszym dorobku o takim ideologicznym nacechowaniu. Należy zaznaczyć, że z żadnym ze wspomnianych dwóch reżyserów żydowskich, którzy przeżyli wojnę, nigdy już nie ponowił on współpracy.

Beck U., Grande E., Europa kosmopolityczna. Społeczeństwo i polityka w drugiej nowoczesności, przeł. A. Ochocki, Warszawa 2009

Bergfelder T., Love beyond the nation. Cosmopolitanism and transnational desire in cinema, [w:] Europe and Love in Cinema, red. L. Passerini, J. Labanyi, K. Diehl, Bristol, Chicago 2012

Brockmann S., A Critical History of German Film, Rochester 2010

Brun L., Dzikie pola (Szkic scenariusza do filmu dźwiękowego. Prawa autorskie zastrzeżone), cz. 1, „Kino” 1930, nr 21

Brun L., Dzikie pola (Szkic scenariusza do filmu dźwiękowego. Prawa autorskie zastrzeżone), cz. 2, „Kino” 1930, nr 22 
Bruns J.F., Nazi Cinema's New Women. Marika Rokk, Zarah Leander, Kristina Soderbaum, Stanford 2002

Cirlot J.E., Słownik symboli, przeł. I. Kania, Kraków 2001

Danielewicz M., Ford reżyser, Warszawa 2019

Drewniak B., Teatr i film III Rzeszy. W systemie hitlerowskiej propagandy, Gdańsk 2011

Ford R., Tajne bronie III Rzeszy, przeł. P. Butkiewicz, Warszawa 2000

Gross N., Film żydowski w Polsce, przeł. A. Ćwiakowska, Kraków 2002

Grunberger R., Historia społeczna Trzeciej Rzeszy, przeł. W. Kalinowski, Warszawa 1994

Gwóźdź A., Zaklinanie rzeczywistości. Filmy niemieckie i ich historie 1933-1949, Wrocław 2018

Hake S., Popular Cinema of the Third Reich, Austin 2001

Helker R., Lenssen C., Der Tschechow-Clan. Die Geschichte einer deutsch-russischen Künstlerfamilie, Berlin 2001

Helker R., Die Tschechows. Wege in die Moderne, Berlin 2005

Heywood A., Ideologie polityczne wprowadzenie, przeł. M. Habura, N. Orłowska, D. Stasiak, Warszawa 2007

Holliday J., Sirk on Sirk. Conversations with Jon Holliday, London 2010

Housden M., Hitler: Study of a Revolutionary?, Routlege 2000

I, Nowy film polski „Dzikie pola”, „Kurier Nowogródzki” 1931, nr 40

Klinger B., Melodrama and Meaning: history, culture, and the films of Douglas Sirk, Bloomington 1994

Kłys T., Od Mabusego do Goebbelsa. Weimarskie filmy Fritza Langa i kino niemieckie do roku 1945, Łódź 2013

Knoph V., Martens S., Görings Reich. Selbstinszenierungen in Carinhall, Berlin 2006

Korczyński T.M., Kiedy dom zaczyna płonacć. Swój, obcy, wróg w Trzeciej Rzeszy z perspektywy konstruktywistycznej socjologii wiedzy, Gdańsk 2019

Kracauer S., Od Caligariego do Hitlera. Z psychologii filmu niemieckiego, przeł. E. Skrzywanowa, W. Wertenstein, Gdańsk 2009

Kreimeier K., The UFA Story: A History of Germany's Greatest Film Company, 1918-1945, przeł. R. Kimber, R. Kimber, Berkeley 1996

Luba I., Berlin. Szalone lata dwudzieste - nocne życie i sztuka, Warszawa 2013

Mazur D., Pacyfistyczny duch nad Dzikimi polami, [w:] Europa Środkowo-Wschodnia. Trudny dialog, red. J. Getka, R. Kramar, Warszawa 2015

McCormick R.W., Gender and Sexuality in Weimar Modernity. Film, Literature, and "New Objectivity", London 2001

Nicolella H., Frank Wisbar. The Director of Ferryman Maria, from Germany to America and Back, Jefferson 2017

Od poetyki przestrzeni do geopoetyki, red. E. Konończuk, E. Sidoruk, Białystok 2012

Patek A., Żydzi w drodze do Palestyny 1934-1945. Szkice z dziejów aliji bet nielegalnej imigracji żydowskiej, Kraków 2009

Petz A., „Sto szabel błysnęło w słońcu”. Warszawska premiera filmu Dzikie pola Józefa Lejtesa, [w:] 1918 - kino polskie wobec odzyskania niepodległości, red. M. Guzek, P. Zwierzchowski, Bydgoszcz 2020

Porter A.K., Rentschler E., The Ministry of Illusion: Nazi Cinema and its Afterlife, Harvard 1996

Preizner J., Aleksander Ford - car PRL-owskiego kina, [w:] Autorzy kina polskiego, t. 2, red. G. Stachówna, B. Zmudziński, Kraków 2007

Pryt K., Polskie elementy w nazistowskiej polityce filmowej 1933-1939, „Pleograf. Kwartalnik Akademii Polskiego Filmu" 2019, nr 1

Rachwald T., „Aleksander Ford” człowiek zmyślony. Tożsamość i polityka w Sabrze (1933) $i$ Drodze młodych (1936), „Kwartalnik Filmowy” 2015, nr 92 
Rother R., Leni Riefenstahl. The Seduction of Genius, London, New York 2002

Ryan T., The Films of Douglas Sirk: Exquisite ironies and magnificent obsessions, Jackson 2019

Rybicka E., Geopoetyka. Przestrzeń i miejsce we współczesnych teoriach i praktykach literackich, Kraków 2014

Rybicka E., Geopoetka, geokrytyka, geokulturologia. Analiza porównawcza pojęć, „Białostockie Studia Literaturoznawcze” 2011, nr 2

Schindler Z., Rozmowa o „Dzikich Polach” w Berlinie (Korespondencja własna), „Kino” 1931, nr 38

Schulte-Sasse L., Entertaining the Third Reich. Illusions of wholeness in Nazi cinema, Durham 1996

Spielhofer H., An der Kamera. Franz Weihmayr, "Der Deutsche Film” 1938, nr 4 (April)

Thompson K., Narodziny i schyłek „Filmowej Europy”, [w:] Kino Europy, red. P. Sitarski, Kraków 2001

Wspomnienia Józefa Lejtesa (cz. I), „Tygiel Kultury” 1997, nr 5

Zahorska S., Kronika filmowa, „Wiadomości Literackie” 1932, nr 13

Źródła internetowe:

<https://encyklopedia.pwn.pl/haslo/Paneuropa;3953811.html>, dostęp: 12.03.2020

$<$ https://www.filmportal.de/en/person/franz-weihmayr_f303075915672226e0305 3d50b375262> dostęp: 12.03.2020

<http://www.fn.org.pl/page/index.php?str=521>, dostęp: 12.03 .2020

<https:/www.imdb.com/name/nm0005925/>, dostęp: 12.03.2020 